University of Nebraska - Lincoln

DigitalCommons@University of Nebraska - Lincoln

USDA Forest Service / UNL Faculty Publications U.S. Department of Agriculture: Forest Service -National Agroforestry Center

2013

Development History and Bibliography of the U.S. Forest Service Crown-Condition Indicator for Forest Health Monitoring

KaDonna C. Randolph

U.S. Department of Agriculture- Forest Service

Follow this and additional works at: https://digitalcommons.unl.edu/usdafsfacpub

Randolph, KaDonna C., "Development History and Bibliography of the U.S. Forest Service Crown-Condition Indicator for Forest Health Monitoring" (2013). USDA Forest Service / UNL Faculty Publications. 257. https://digitalcommons.unl.edu/usdafsfacpub/257

This Article is brought to you for free and open access by the U.S. Department of Agriculture: Forest Service -National Agroforestry Center at DigitalCommons@University of Nebraska - Lincoln. It has been accepted for inclusion in USDA Forest Service / UNL Faculty Publications by an authorized administrator of DigitalCommons@University of Nebraska - Lincoln. 


\title{
Development history and bibliography of the US Forest Service crown-condition indicator for forest health monitoring
}

\author{
KaDonna C. Randolph
}

This article is a U.S. government work, and is not subject to copyright in the United States.

Received: 5 June 2012 / Accepted: 24 September 2012 /Published online: 6 October 2012

(C) Springer Science+Business Media Dordrecht (outside the USA) 2012

\begin{abstract}
Comprehensive assessment of individualtree crown condition by the US Department of Agriculture, Forest Service, Forest Inventory and Analysis (FIA) Program has its origins in the concerns about widespread forest decline in Europe and North America that developed in the late 1970s and early 1980s. Programs such as the US National Acid Precipitation Assessment Program, US National Vegetation Survey, Canadian Acid Rain National Early Warning System, and joint USCanadian North American Sugar Maple Decline Project laid the groundwork for the development of the US Forest Service crown-condition indicator. The crown-condition assessment protocols were selected and refined through literature review, peer review, and field studies in several different forest types during the late 1980s and early 1990s. Between 1980 and 2011, 126 publications relating specifically to the crown-condition indicator were added to the literature. The majority of the articles were published by the US Department of Agriculture, Forest Service or other State or Federal government agency, and more than half were published after 2004.
\end{abstract}

K. C. Randolph $(\bowtie)$

U.S. Department of Agriculture, Forest Service, 4700 Old Kingston Pike,

Knoxville, TN 37919, USA

e-mail:krandolph@fs.fed.us
Keywords Crown condition · Forest health monitoring · Forest survey history . Visual assessments

\begin{tabular}{|c|c|}
\hline \multicolumn{2}{|c|}{ Abbreviations } \\
\hline ARNEWS & $\begin{array}{l}\text { Acid Rain National Early Warning } \\
\text { System }\end{array}$ \\
\hline EMAP & $\begin{array}{l}\text { Environmental Monitoring and } \\
\text { Assessment Program }\end{array}$ \\
\hline FHM & Forest Health Monitoring \\
\hline FIA & Forest Inventory and Analysis \\
\hline ICP- & International Co-operative Programme \\
\hline Forests & $\begin{array}{l}\text { on Assessment and Monitoring of Air } \\
\text { Pollution Effects on Forests }\end{array}$ \\
\hline NAMP & $\begin{array}{l}\text { North American Sugar Maple Decline } \\
\text { Project }\end{array}$ \\
\hline NAPAP & $\begin{array}{l}\text { National Acid Precipitation Assessment } \\
\text { Program }\end{array}$ \\
\hline NVS & National Vegetation Survey \\
\hline SE & Southeast Loblolly/Shortleaf Pine \\
\hline DEMO & Demonstration \\
\hline UN-ECE & $\begin{array}{l}\text { United Nations Economic Commission } \\
\text { for Europe }\end{array}$ \\
\hline VDS & Visual Damage Survey \\
\hline
\end{tabular}

\section{Introduction}

Visual assessment of tree crown transparency is included in many forest health inventories currently implemented throughout the world and as such is 
indeed "an almost universal index of tree health" (Innes 1993, p. 233). As the tree's principal engine for energy capture, full, vigorous crowns generally are associated with more vigorous growth rates. Since trees undergoing stress often react by slowing growth and shedding parts of the crown (Millers et al. 1989), visually inspecting crowns for damaged or missing foliage provides insight into the overall condition of the tree. Though the modern application of tree crown condition as a forest health indicator has its origins in the concerns about forest decline in Europe and North America that developed in the late 1970s and early 1980 s, foresters probably have used visual assessments of crown conditions since the beginning of the profession. Publications document their use in the USA as early as the 1920s (e.g., Ehrlich 1939; Snell 1931); however, it was not until the 1980s that the USA established large-scale monitoring efforts to study forest decline in part through crown condition assessments (Innes 1993).

After their inception, the monitoring programs, as well as the individual crown assessment variables, evolved in response to changing information and programmatic needs. In 2007, Schomaker et al. published a state-of-the-art guide to the crowncondition classification methods recommended by the US Department of Agriculture, Forest Service. The guide outlined the justification for using crown-condition classification to assess forest health alongside the procedures for data collection, data quality control, and data analysis. Their report did not, however, describe the historical development of the crown-condition classification methods from their infancy in the 1980s. Since much of this history lies in internal reports and the institutional memory of those personally involved with the methods' development, the purpose of this review is to succinctly document the development of the crown-condition classification methods outlined by Schomaker et al. (2007) from the late 1980s through 2010. As with the methodology's history, much of the crown-assessment research is dispersed throughout the literature, often composing only a small part of a larger forest inventory or forest health study. Such results may be difficult to locate in a standard literature search; therefore, a bibliography of articles related to the Forest Service crown-assessment methodology is included with this review.

\section{Initial development of crown-condition assessment protocols}

In 1982, in response to concern about the possibility of widespread damage to forests by air pollution, Germany became the first country to implement a national program to assess crown condition (Redfern and Boswell 2004). Included in the assessments were two primary variables, defoliation (percentage of leaf or needle loss), and discoloration (percentage of discolored foliage in the crown) (Anderson and Belanger 1987). In 1984, Great Britain followed Germany's example and established a national monitoring program based on the German methodology (Redfern and Boswell 2004). A year later, the United Nations Economic Commission for Europe established an international cooperative program for forest monitoring known as the "International Co-operative Programme on Assessment and Monitoring of Air Pollution Effects on Forests" or ICP-Forests (Innes 1993). The need for a large-scale grid of monitoring plots across Europe was agreed upon at the first program task force meeting on October 4, 1985 in Freiburg, Germany (ICP-Forests 2010), and in 1987, annual assessment of forest condition became mandatory throughout the European Union (Redfern and Boswell 2004). Assessments of crown condition, and defoliation in particular, served as the foundation of the ICP-Forests program (Eichhorn et al. 2010).

In North America, the US National Acid Precipitation Assessment Program was created in 1980 to study atmospheric deposition and its effects on aquatic and terrestrial ecosystems (Bechtold et al. 2007). This led to the US Forest Service launching the National Vegetation Survey (NVS) in 1984 with an objective to design a long-term approach to forest health monitoring (Bechtold et al. 2007). That same year, the Canadian Forestry Service established the Acid Rain National Early Warning System (ARNEWS) in order to detect early signs of forest damage (D'Eon et al. 1994). Original ARNEWS field methods were modified in 1985, finalized in 1986, and included assessments of shoots, branches, dieback, live crown width, live crown length, and needle retention (D'Eon et al. 1994).

\section{Development of the US Forest Service crown-condition indicator}

Following the initial activities of the early 1980 s, a series of events took place in the USA which 
eventually established the crown-condition assessments currently utilized by the US Forest Service Forest Inventory and Analysis (FIA) Program:

1986 Anderson and Belanger (1987) implemented a study in the Georgia and South Carolina Piedmont to establish a crown rating method for loblolly (Pinus taeda) and shortleaf (Pinus echinata) pines. Basing their methods on the German methodology, they discovered that needle loss percentage was a sufficient and reliable estimator of tree and stand vigor and that assessing foliage discoloration was unnecessary.

1987 In January, scientists from Canada and the USA met in Burlington, Vermont, to discuss the status of sugar maple (Acer saccharum) decline in southeastern Canada and northeastern USA (McFadden 1991). As a result of their meeting, a joint research effort known as the North American Sugar Maple Decline Project (NAMP) was formulated to assess if, and where, decline of sugar maple was occurring. A field manual detailing instructions for plot selection, plot establishment, and data collection included instructions for assessing crown dieback, transparency, discoloration, dwarfed foliage, epicormic branching, and defoliation (Millers et al. 1991).

In November, NVS personnel and the US Atmospheric Impacts Research Program held a Forest Damage Survey Workshop in Chapel Hill, North Carolina, to identify, evaluate, and recommend variables and procedures necessary for assessing the condition of forests in the eastern USA (Alexander et al. 1992).

1988 Initial tree vigor ratings were made on newly established NAMP field plots (McFadden 1991).

The list of variables identified at the 1987 NVS workshop were refined by a committee and compiled with field procedures into a manual for a Visual Damage Survey (VDS). Among the variables included in the VDS were the European ratings of discoloration and defoliation, Anderson and Belanger's (1987) loblolly and shortleaf pine crown ratings, and other assessments of foliage and branch condition (Alexander et al. 1992). In mid-July to midSeptember, VDSs were conducted in mixed hardwood stands in the central hardwood region, high elevation spruce-fir (Picea-Abies) forests in the northeast, and loblolly pine forests in the Piedmont (Alexander et al. 1992).

The US Environmental Protection Agency established the Environmental Monitoring and Assessment Program (EMAP) to monitor the status and trends in the condition of ecological resources, develop innovative methods for anticipating emerging environmental problems, and provide a greater capacity for assessing and monitoring the condition of the nation's ecological resources (Messer et al. 1991).

1989 NAMP field plots established in 1988 were remeasured (McFadden 1991).

In mid-July to mid-September, NVS personnel implemented a VDS in loblolly pine forests in the Southeastern Coastal Plain (Alexander et al. 1992).

1990 The NVS and forest-related aspects of EMAP were combined to create the US Forest Health Monitoring (FHM) Program (Bechtold et al. 2007), and forest health detection monitoring plots were established in Maine, New Hampshire, Vermont, Massachusetts, Connecticut, and Rhode Island. Among the variables assessed on these plots were crown dieback, foliage transparency, discoloration, and needle retention (Table 1) (Brooks et al. 1992). The FHM Program also initiated a plot design and logistics study known as the "20/20 study" to evaluate the plot design, subsampling procedures, time and resource requirements, and method efficiencies for detection monitoring. The study consisted of 20 field plots in New England northern hardwood forest types and 20 field plots in loblolly pine-hardwood forest types in Virginia (Riitters et al. 1992).

1991 The FHM Program continued establishment of forest health detection monitoring plots by adding plots in New Jersey, Delaware, Maryland, Virginia, Georgia, and Alabama. Pilot studies were initiated in Colorado and California (Alexander and Palmer 1999) (see Fig. 1 for subsequent state entries into the FHM Program).

1992 The FHM Program initiated a 2-year demonstration study known as the Southeast Loblolly/ Shortleaf Pine Demonstration (SE DEMO) to evaluate selected indicators across the Atlantic Coastal and Piedmont loblolly shortleaf pine forest type (Lewis and Conkling 1994). 
Table 1 Crown-condition variables recorded by the US Forest Health Monitoring Program (1990-1999) and US Forest Inventory and Analysis Program (2000-2010)

\begin{tabular}{|c|c|c|c|}
\hline Variable & Stem size included & Protocol changes & Field protocol documentation \\
\hline Crown class & $\begin{array}{l}\text { Trees }^{\mathrm{a}} \\
\text { Saplings }\end{array}$ & Recorded consistently 1990-1996, 2000-2010 & Conkling and Byers (1992) \\
\hline Crown density & Trees & Recorded consistently 1990-2010 & Schomaker et al. (2007) \\
\hline Crown dieback & Trees & Recorded consistently 1990-2010 & Schomaker et al. (2007) \\
\hline Crown diameter & $\begin{array}{l}\text { Trees } \\
\text { Saplings }\end{array}$ & Recorded consistently 1990-1999 & Schomaker et al. (2007) \\
\hline Crown form & $\begin{array}{l}\text { Trees } \\
\text { Saplings }\end{array}$ & Recorded in the west only, 1992-1993 & Conkling and Byers (1992) \\
\hline Crown light exposure & $\begin{array}{l}\text { Trees } \\
\text { Saplings }\end{array}$ & $\begin{array}{l}\text { Initially implemented in } 1997 \text {. Current coding } \\
\text { system adopted in } 1998 \text { and applied } \\
\text { consistently through } 2010\end{array}$ & Schomaker et al. (2007) \\
\hline Crown position & $\begin{array}{l}\text { Trees } \\
\text { Saplings }\end{array}$ & Recorded consistently 1997-2010 & Schomaker et al. (2007) \\
\hline Discoloration & Trees & Recorded in 1990 & Zedaker and Nicholas (1990) \\
\hline Foliage transparency & Trees & Recorded consistently 1990-2010 & Schomaker et al. (2007) \\
\hline Needle retention & Trees & $\begin{array}{l}\text { Recorded for nine coniferous species } \\
\quad(\text { Abies, Picea, and Pinus), 1990-1992 }\end{array}$ & Chojnacky (1991) \\
\hline Seedling vigor & Seedlings $^{\mathrm{d}}$ & Recorded consistently 1990-1999 & Conkling and Byers (1992) \\
\hline Sapling crown vigor & Saplings & Recorded consistently 1990-2010 & Schomaker et al. (2007) \\
\hline Live crown ratio & $\begin{array}{l}\text { Trees } \\
\text { Saplings }\end{array}$ & $\begin{array}{l}\text { Recorded in } 5 \% \text { increments, } 1990-2004 \text {. } \\
\text { Recorded in } 1 \% \text { increments } 2005-2010 \text {. } \\
\text { In } 2005 \text {, the tree length in the denominator } \\
\text { of the ratio was changed to the actual } \\
\text { length as defined by the FIA variable } \\
\text { "actual tree length" (USDA 2007) }\end{array}$ & Schomaker et al. (2007) \\
\hline
\end{tabular}

\footnotetext{
${ }^{\text {a }}$ Diameter at least 5.0 in. at breast height $(4.5 \mathrm{ft})$ or root collar

${ }^{\mathrm{b}}$ Diameter at least $1.0 \mathrm{in}$. and less than $5.0 \mathrm{in}$. at breast height $(4.5 \mathrm{ft})$ or root collar

${ }^{\mathrm{c}}$ Optional measurement

${ }^{\mathrm{d}}$ Single-stemmed tree species at least $1.0 \mathrm{ft}$ in height but less than $1.0 \mathrm{in}$. in diameter at breast height $(4.5 \mathrm{ft})$ and multistemmed tree species with no stem larger than $1.0 \mathrm{in}$. at the root collar
}

2000 The FHM Program detection monitoring plots were integrated into the FIA Program (Riitters and Tkacz 2004). The date of initial crowns data collection by FIA for states not involved originally through the FHM Program is given in Fig. 1.

The initial crown-condition assessment variables included by the FHM Program in 1990 (Table 1) were selected by peer review, expert opinion, and literature review. Selections were influenced by the variables included by Anderson and Belanger (1987) and in the NAMP and to a lesser extent by the European assessments and the VDS. Using the results of the 20/20 study, the SE DEMO, and the inaugural detection monitoring plots established in the eastern USA, the initial variables were refined through an evaluation based on six criteria: unambiguous interpretability, quantification simplicity, signal-to-noise ratio, regional responsiveness, index period stability, and environmental impact (Alexander and Barnard 1992; Lewis and Conkling 1994). Changes to the initial crowncondition assessment variables resulting from this and subsequent evaluations are outlined in Table 1. In general, the US Forest Service crown-condition assessment protocols have been stable since 2000 .

\section{Applications of crown-condition assessments}

Long-term studies and thorough evaluations of historic patterns of mortality showed that the claims of 
Fig. 1 Year crown-condition data collection was initiated by the US Forest Health Monitoring Program (gray states) or US Forest Inventory and Analysis Program, by state, 1990-2010

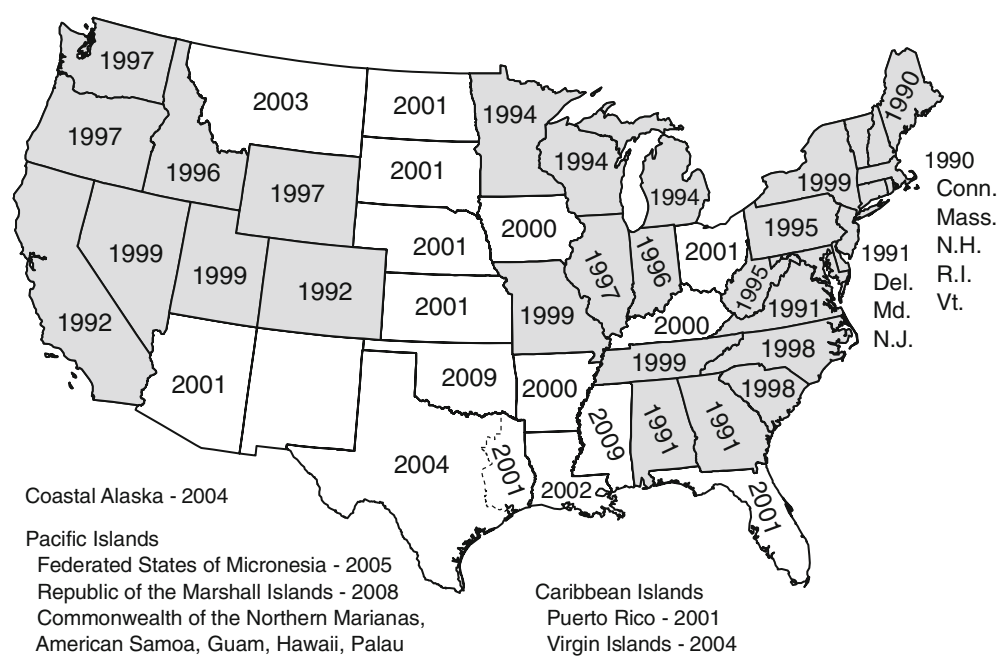

widespread forest decline due to atmospheric deposition, i.e., the primary motivation behind the initial development of crown-condition assessment protocols, were largely inaccurate (Innes 1993; Allen et al. 1995; Hall 1995). Despite this conclusion, crowncondition assessments have remained a part of forest health monitoring programs and found expanded use in individual research projects.

Crown-condition assessments have been used in a variety of individual research projects, ranging from identifying the effects of military training operations and silvicultural practices on forest stands (Applegate and Steinman 2005; Starkey and Guldin 2004) to describing the effect of insects and diseases on individual species (e.g., Petrillo et al. 2005; Rentch et al. 2009). Such studies, and other general summaries of crown-condition data, provide a wealth of information about individual tree and forest health, but many have been published in conference proceedings or by State or Federal agencies. As a result, they do not always appear in major literature citation databases and may go undiscovered in a standard literature search. The following bibliography compiles the current (2011) literature related to the FHM-FIA crown-condition indicator as a resource for researchers and forest managers who may be considering implementing crowncondition assessments.

\section{Bibliography scope}

Four citation databases (CAB Abstracts, AGRICOLA, Scopus, and Web of Science ${ }^{\mathrm{SM}}$ ) were searched for articles containing the following keywords individually in "all fields" (AGRICOLA and Scopus) or as "terms anywhere" (CAB Abstracts and Web of Science ${ }^{\mathrm{SM}}$ ): crown condition(s), crown density, foliage or foliar transparency, crown transparency, crown dieback, sapling crown vigor, crown ratio, crown diameter, and crown light exposure. Searches were limited to articles (English-language only) published between January 1, 1980 and December 31, 2011 and that also included the terms "forest inventory and analysis" or "forest health monitoring." The same search was implemented in Treesearch (http://www.treesearch.fs.fed.us), an on-line database housing public domain publications written by US Forest Service Research and Development scientists. All searches were conducted in February 2012. Publications from all of the searches were examined to ensure that the US Forest Service crown-condition indicator was used specifically.

Bibliography organization

All of the references were sorted into categories describing whether the crown-condition data were collected under the administration of the FHM Program, the FIA Program, or other independent individual or organization (Section I), the level of reporting (state, regional, or national) (Section II), the geographic location of the study (Section III), and which crowncondition variables were utilized or reported (Section IV). Special categories were created for quality assurance and quality control discussions (Section V), indicator development and field method guides (Section VI), and allometric modeling, estimation procedures, and other correlation or predictive models (Section 
VII). For Section I, the period of FIA Program administration generally began in the year 2000. The composite variables in Section IV-G are crown defoliation index, crown production efficiency, crown shape ratio, crown structure index, crown surface area, crown volume, relative crown amount, total crown losses, visual crown rating, and the ZB index. The "other" crowncondition variables in Section IV-H are crown light exposure, crown position, crown class, discoloration, needle retention, and dwarfed foliage. References may appear in multiple categories.

\section{Bibliography summary}

A total of 26 unique references from the citation database search met the required criteria. To this, 33 references were added from the Treesearch database and an additional 67 references from my own personal library, for a total of 126 references ("Appendix"). Theses, dissertations, poster presentations, and articles that may have appeared in newspapers or popular magazines were not included. The majority of the references included in the bibliography were published by the US Forest Service or other State or Federal government agency (Fig. 2). Other sources were conference proceedings (all but two of which were published by the US Forest Service), peer-reviewed journals, and books. The 24 journal articles were distributed across 13 different journals. Slightly more than half of the articles were published after 2004 (Fig. 3).

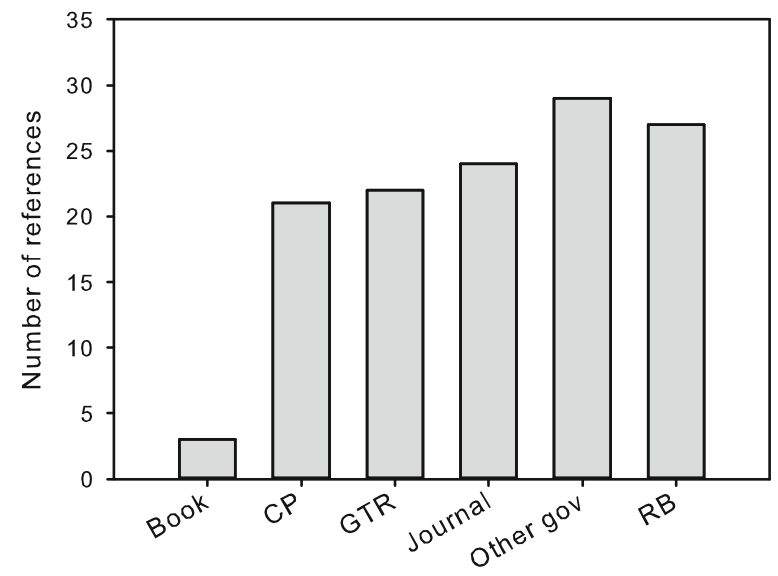

Fig. 2 Number of references in the crown-condition indicator bibliography (Appendix) by publication type. $C P$ conference proceedings, GTR US Forest Service General Technical Report, Other gov State or Federal Government publication (other than GTR or RB), $R B$ US Forest Service Resource Bulletin

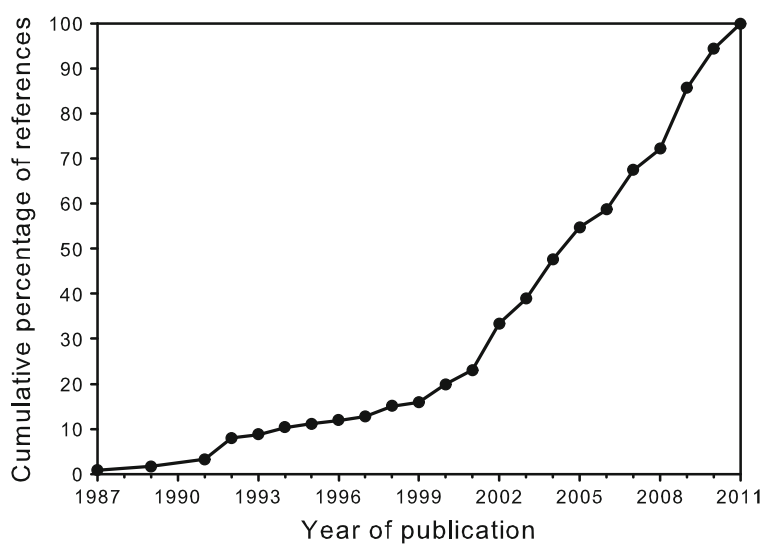

Fig. 3 Cumulative percentage of references in the crowncondition indicator bibliography ("Appendix"), by publication year

\section{Conclusion}

A rich history of cooperation and collaboration led to the development of crown-condition assessment protocols in the USA. Those established by the FHM Program and now implemented by the FIA Program have been utilized in a variety of forested conditions both domestically and internationally and provide individual researchers, local communities, and even entire nations options upon which they may develop their own systems to monitor forest health.

Acknowledgments I would like to thank Bill Bechtold, Bill Burkman, Barbara Conkling, Manfred Mielke, Dale Starkey, Jim Steinman, and Ken Stolte for their assistance in outlining the chronology of the crown-condition indicator development and Barbara Conkling and Beth Schulz for their comments on the initial draft of this manuscript.

\section{Appendix: Bibliography}

I. Administration of data collection

A. US Forest Health Monitoring Program

$1,3,4,7,9,11,13,14,18,20,22,24,26$, $28,30,32,34,35,36,37,42,48,49,52,54$, $56,58,59,62,63,64,65,66,67,68,69,70$, $71,72,73,74,75,76,77,82,84,86,97,98$, $100,108,110,111,112,113,126$

B. US Forest Inventory and Analysis Program $10,12,15,16,17,19,25,27,29,33,34$, $35,36,40,43,44,48,53,55,57,59,60,61$, $78,80,81,83,85,87,88,89,90,92,93,94$, 
$95,101,102,103,104,106,110,114,115$, $116,117,118,121,122,123,124$

C. Other

$6,23,38,39,41,45,46,47,50,51,79,91$, $96,99,105,107,109,119,120,125$

II. Level of reporting

A. State

$15,16,19,25,27,29,33,38,39,40,43$, $44,49,53,55,57,60,61,65,66,67,68,69$, $70,71,72,73,74,75,76,77,78,80,81,87$, $92,100,101,102,103,104,115,117,118$, 122,124

B. Regional

$1,7,13,18,22,26,42,54,84,88,89,90$, $95,98,110,113$

C. National

$4,7,34,35,36,37,83,116$

III. Geographic location

A. Northeastern USA (Connecticut, Maine, Massachusetts, New Hampshire, New York, Rhode Island, Vermont)

$1,3,4,7,9,18,20,23,25,31,34,35,36$, $37,39,41,42,53,54,60,61,66,68,70,71$, $73,75,76,83,87,90,105,108,110,111$, $112,116,119,120,121$

B. Mid-Atlantic USA (Delaware, Maryland, New Jersey, Ohio, Pennsylvania, West Virginia)

$1,3,4,7,9,34,35,36,37,39,42,50,54$, $55,62,63,64,67,69,72,74,77,83,96,108$, $110,111,116,117,118,125$

C. Southern USA (Alabama, Arkansas, Florida, Georgia, Kentucky, Louisiana, Mississippi, North Carolina, Oklahoma, South Carolina, Tennessee, Texas, Virginia)

$1,3,4,6,7,9,12,13,19,20,22,33,34,35,36$, $37,42,43,45,48,51,52,56,78,82,83,84,85,86$, 93, 94, 101, 102, 103, 104, 109, 111, 115, 116, 126

D. North Central USA (Illinois, Indiana, Iowa, Kansas, Michigan, Minnesota, Missouri, Nebraska, North Dakota, South Dakota, Wisconsin)

$3,4,7,9,31,34,35,36,37,38,57,65,79,80$, 81, 83, 87, 89, 91, 92, 110, 111, 113, 116, 122, 124

E. Interior West USA (Arizona, Colorado, Idaho, Montana, Nevada, New Mexico, Utah, Wyoming)
$4,7,11,34,35,36,37,44,49,83,95,98$, 100, 108, 114, 116

F. West Coast USA (Alaska, California, Hawaii, Oregon, Washington)

$4,7,11,24,26,27,29,34,35,36,37,40$, 59, 83, 88, 108, 116, 121

G. Caribbean USA (Puerto Rico, US Virgin Islands)

$15,16,17$

H. International

$31,46,47,99,107$

IV. Crown condition variables reported or utilized

A. Crown density

$1,2,6,7,12,13,15,16,19,20,22,25,26$, $27,29,30,33,38,39,40,41,42,43,45,46$, $47,48,49,51,53,54,58,60,61,63,65,66$, $67,68,69,70,71,72,73,74,75,76,77,78$, $82,83,84,88,89,90,91,92,93,94,95,96$, $98,99,100,101,102,103,104,106,109$, $110,111,113,115,116,124,126$

B. Crown dieback

$2,3,4,6,7,13,15,16,18,19,20,21$, $22,24,25,26,27,29,30,31,34,35,36$, $37,38,39,40,41,42,43,44,45,46,47$, $48,49,50,51,52,53,54,55,57,58,60$, $61,62,63,64,65,66,67,68,69,70,71$, $72,73,74,75,76,77,78,79,80,81,82$, $83,84,87,88,89,90,91,92,93,95,96$, 98, 99, 100, 101, 102, 103, 104, 105, 106, $108,109,110,111,112,113,115,116$, $117,118,121,122,124,125,126$

C. Foliage transparency

$1,4,7,13,15,16,18,19,20,21,22,23$, $24,25,26,27,29,30,31,34,35,36,37,38$, $40,41,42,43,44,45,46,47,48,49,50,51$, $52,53,54,56,57,60,61,63,66,67,68,69$, $70,71,72,73,74,75,76,77,78,79,80,81$, $82,83,84,88,89,90,91,92,93,95,96,98$, $99,100,101,102,103,104,105,106,107$, $108,109,110,111,112,113,115,116,122$, 125,126

D. Sapling crown vigor

$13,22,24,26,42,65,88,89,90,92,95$, $101,102,103,106,116,121,124$

E. Uncompacted live crown ratio

$10,11,12,14,15,16,24,33,41,42,44$, $45,46,47,51,52,56,57,58,59,63,80,81$, $85,96,106,114,116,119,120,122,126$ 
F. Crown diameter

$9,11,12,14,17,30,33,46,47,51,52,56$,

$58,86,106,120,126$

G. Composite variables

$4,12,30,33,34,35,36,42,46,47,52,58$, $82,96,106,126$

H. Other

$9,15,16,18,21,42,106,109,116,120,126$

V. Quality assurance/quality control $10,18,21,30,31,52,58,106,116$

VI. Indicator development and field method guides $2,5,7,8,14,28,30,32,52,58,106$

VII. Modeling and estimation $9,10,11,14,17,59,85,86,107,111,114$, 123,126

\section{Citations}

1. Alexander, S. A., \& Bernard, D. R. (1994). Forest health monitoring 1992 annual statistical summary. EPA/620/R-94/010. Research Triangle Park, NC: US Environmental Protection Agency.

2. Alexander, S. A., Carlson, J. A., \& Barnard, J. E. (1992). The visual damage survey: a study to evaluate the eastern forest condition. In D. H. McKenzie, D. E. Hyatt, \& V. J. McDonald (Eds.), Ecological indicators (pp. 361-372). New York, NY: Elsevier Applied Science.

3. Alexander, S. A., \& Palmer, C. J. (1999). Forest health monitoring in the United States: First four years. Environmental Monitoring and Assessment, 55, 267-277.

4. Ambrose, M. J. (2004). Criterion 3-maintenance of ecosystem health and vitality: Indicator 17: Area and percentage of forest land with diminished biological components indicative of changes in fundamental ecological processes and/or ecological continuity. In D. R. Darr (Coord.), Data report: A supplement to the national report on sustainable forests-2003. FS766A. Washington, DC: U.S. Department of Agriculture, Forest Service. http://www.fs.fed.us/ research/sustain/2003SustaintabilityReport/ summariesandsupporting\%20analyses.htm. Accessed 20 January 2006.

5. Anderson, R. L., \& Belanger, R. P. (1987). A crown rating method for assessing tree vigor of loblolly and shortleaf pines. In D. R. Phillips
(Comp.), Proceedings of the fourth biennial southern silvicultural research conference; 1986 November 4-6, Atlanta, GA (pp. 538-543). Asheville, NC: U.S. Department of Agriculture, Forest Service, Gen. Tech. Rep. SE-42.

6. Applegate, J. R., \& Steinman, J. (2005). A comparison of tree health among forest types and conditions at Fort A.P. Hill, Virginia. Southern Journal of Applied Forestry, 29, 143-147.

7. Bechtold, W., Randolph, K., \& Zarnoch, S. (2009). The power of FIA phase 3 crown-indicator variables to detect change. In W. McWilliams, G. Moisen, R. Czaplewski, (Comps.), Forest Inventory and Analysis (FIA) Symposium 2008; October 21-23, 2008; Park City, UT. Proc. RMRS-P-56CD. Fort Collins, CO: U.S. Department of Agriculture, Forest Service, Rocky Mountain Research Station.

8. Bechtold, W., Tkacz, B., \& Riitters, K. (2007). The historical background, framework, and application of forest health monitoring in the United States. In Proceedings: International Symposium on Forest Health Monitoring: 2007 January 30-31, Seoul (pp. 19-40). Korea Forest Service.

9. Bechtold, W. A. (2003). Crown-diameter prediction models for 87 species of stand-grown trees in the Eastern United States. Southern Journal of Applied Forestry, 27, 269-278.

10. Bechtold, W. A. (2003). Crown position and light exposure classification - an alternative to field-assigned crown class. Northern Journal of Applied Forestry, 20, 154-160.

11. Bechtold, W. A. (2004). Largest-crown-width prediction models for 53 species in the Western United States. Western Journal of Applied Forestry, 19, 245-251.

12. Bechtold, W. A., \& Coulston, J. W. (2005). Detection monitoring of crown condition in South Carolina: A case study. In R. E. McRoberts, G. A Reams, P. C. Van Deusen, \& W. H. McWilliams (Eds.), Proceedings of the fifth annual forest inventory and analysis symposium; 2003 November 1820; New Orleans, LA. Washington, DC: U.S. Department of Agriculture, Forest Service, Gen. Tech. Rep. WO-69.

13. Bechtold, W. A., Hoffard,W. H., \& Anderson, R. L. (1992). Summary report: Forest health monitoring in the South, 1991. Asheville, NC: U.S. Department 
of Agriculture, Forest Service, Southeastern Forest Experiment Station, Gen. Tech. Rep. SE-081.

14. Bechtold, W. A., Mielke, M. E., \& Zarnoch, S. J. (2002). Comparison of field methods and models to estimate mean crown diameter. Northern Journal of Applied Forestry, 19, 177-182.

15. Brandeis, T. J., Helmer, E. H., \& Oswalt, S. N. (2007). The status of Puerto Rico's forests, 2003. Asheville, NC: U.S. Department of Agriculture, Forest Service, Southern Research Station, Resour. Bull. SRS-119.

16. Brandeis, T. J., \& Oswalt, S. N. (2007). The status of U.S. Virgin Islands' forests, 2004. Asheville, NC: U.S. Department of Agriculture Forest Service, Southern Research Station, Resour. Bull. SRS-122.

17. Brandeis, T. J., Randolph, K. C., \& Strub, M. R. (2009). Modeling Caribbean tree stem diameters from tree height and crown width measurements. International Journal of Mathematical and Computational Forestry \& Natural-Resource Sciences, 1, 78-85.

18. Brooks, R. T., Dickson, D. R., Burkman, W. B., Millers, I., Miller-Weeks, M., Cooter, E., \& Smith, L. (1992). Forest health monitoring in New England: 1990 annual report. Radnor, PA: U.S. Department of Agriculture, Forest Service, Northeastern Forest Experiment Station, Resour. Bull. NE-125.

19. Brown, M. J., New, B. D., Oswalt, S. N., Johnson, T. G., \& Rudis, V. A. (2006). North Carolina's forests, 2002. Asheville, NC: U.S. Department of Agriculture Forest Service, Southern Research Station, Resour. Bull. SRS-113.

20. Burkman, W. G., \& Bechtold, W. A. (2000). Has Virginia pine declined? The use of Forest Health Monitoring and other information in the determination. In M. Hansen \& T. Burk (Eds.), Integrated tools for natural resources inventories in the 21st century: an international conference on the inventory and monitoring of forested ecosystems; 1998 August 16-19; Boise, ID (pp. 258-264). St. Paul, MN: U.S. Department of Agriculture, Forest Service, North Central Research Station, Gen. Tech. Rep. NC-212.

21. Burkman, W. G., Millers, I., \& Lachance, D. (1991). Quality assurance/quality control implementation and evaluation in the North American sugar maple decline project. In D. P. Burns
(Tech. Coord.), Research management for the future; 1990 August 5-11; Montreal, PQ (pp. 29-39). U.S. Department of Agriculture, Forest Service, Gen. Tech. Rep. NE-157.

22. Burkman, W. G., Vissage, J. S., Hoffard, W. H., Starkey, D. A., \& Bechtold, W. A. (1998). Summary report: forest health monitoring in the South, 1993 and 1994. Asheville, NC: U.S. Department of Agriculture, Forest Service, Southern Research Station, Resour. Bull. SRS-32.

23. Burns, B. S., \& Trial, H., Jr. (2000). Recovery of hemlock in Vermont from defoliation by the spring hemlock looper, Lambdina athasaria (Walker). In K. A. McManus, K. S. Shields, \& D. R. Souto (Eds.), Proceedings: Symposium on sustainable management of hemlock ecosystems in eastern North America. Newtown Square, PA: U.S. Department of Agriculture, Forest Service, Northeastern Forest Experiment Station, Gen. Tech. Rep. NE-267.

24. Busing, R. T. (2000). Forest health monitoring in California, Oregon, and Washington: Results and interpretation. In M. Hansen \& T. Burk (Eds.), Integrated tools for natural resources inventories in the 21st century; 1998 August 16-19; Boise, ID (pp. 265-271). St. Paul, MN: U.S. Department of Agriculture, Forest Service, North Central Forest Experiment Station, Gen. Tech. Rep. NC-212.

25. Butler, B. J., Barnett, C. J., Crocker, S. J., Domke, G. M., Gormanson, D., Hill, W. N., et al. (2011). The forests of Southern New England, 2007: A report on the forest resources of Connecticut, Massachusetts, and Rhode Island. Newtown Square, PA: U.S. Department of Agriculture, Forest Service, Northern Research Station, Resour. Bull. NRS-55.

26. Campbell, S., Dale, J., Hooper, C., Ripley, K., \& Schulz, B. (2000). Forest health in west coast forests, 1997-1999. Portland, OR: U.S. Department of Agriculture, Forest Service, Pacific Northwest Research Station.

27. Campbell, S., Waddell, K., \& Gray, A. (2010). Washington's forest resources, 2002-2006: Fiveyear forest inventory and analysis report. Portland, OR: U.S. Department of Agriculture, Forest Service, Pacific Northwest Research Station, Gen. Tech. Rep. PNW-800.

28. Chojnacky, D. C. (Comp.) (1991). Eastern forest health monitoring field measurements guide, 5th 
draft. Research Triangle Park, NC: U.S. Department of Agriculture, Forest Service.

29. Christensen, G. A., Campbell, S. J., \& Fried, J. S. (Tech. eds.) (2008). California's forest resources, 2001-2005: Five-year forest inventory and analysis report. Portland, OR: U.S. Department of Agriculture, Forest Service, Pacific Northwest Research Station, Gen. Tech. Rep. PNW-763.

30. Cline, S. P. (Ed.) (1995). Forest health monitoring: Quality assurance project plan for detection monitoring project/environmental monitoring and assessment program. EPA/620/R-95/002. US Environmental Protection Agency, Las Vegas, NV.

31. Cline, S. P., Burkman, W. G., \& Geron, C. D. (1989). Use of quality control procedures for assessing variation in measurements of forest canopy condition. In R.K Olson \& A.S. Lefohn (Eds.), Effects of air pollution on western forests (pp. 379-393). Anaheim, CA: Air \& Waste Management Association.

32. Conkling, B. L., \& Byers, G. E. (Eds.) (1992). Forest health monitoring field methods guide. Internal Report. Las Vegas, NV: US Environmental Protection Agency.

33. Conner, R. C., Adams, T., Butler, B., Bechtold, W. A., Johnson T. G., Oswalt, S. N., et al. (2004). The state of South Carolina's forests, 2001. Asheville, NC: U.S. Department of Agriculture, Forest Service, Southern Research Station, Resour. Bull. SRS-96.

34. Coulston, J. W., Ambrose, M. J., Riitters, K. H., \& Conkling, B. L. (2005). Forest health monitoring: 2002 national technical report. Asheville, NC: U.S. Department of Agriculture, Forest Service, Southern Research Station, Gen. Tech. Rep. SRS-84.

35. Coulston, J. W., Ambrose, M. J., Riitters, K. H., \& Conkling, B. L. (2005). Forest health monitoring: 2004 national technical report. Asheville, NC: U.S. Department of Agriculture, Forest Service, Southern Research Station, Gen. Tech. Rep. SRS-90.

36. Coulston, J. W., Ambrose, M. J., Riitters, K. H., Conkling, B. L., \& Smith, W. D. (2005). Forest health monitoring: 2003 national technical report. Asheville, NC: U.S. Department of Agriculture, Forest Service, Southern Research Station, Gen. Tech. Rep. SRS-85.

37. Coulston, J. W., Ambrose, M. J., Stolte, K. W., Will-Wolf, S., Smith, G. C., \& Neitlich, P. N.
(2005). Criterion 3-Health and vitality. In B. L. Conkling, J. W. Coulston, \& M. J. Ambrose (Eds.), Forest health monitoring: 2001 national technical report (pp. 39-82). Asheville, NC: U.S. Department of Agriculture, Forest Service, Southern Research Station, Gen. Tech. Rep. SRS-81.

38. Cumming, A. B., Twardus, D. B., Hoehn, R., Nowak, D., Mielke, M., Rideout, R., et al. (2008). Wisconsin street tree assessment, 20022003. Newtown Square, PA: U.S. Department of Agriculture, Forest Service, Northeastern Area State and Private Forestry, NA-FR-02-08.

39. Cumming, A. B., Twardus, D. B., \& Smith, W. D. (2006). National forest health monitoring program, Maryland and Massachusetts street tree monitoring pilot projects. Newtown Square, PA: U.S. Department of Agriculture Forest Service, Northeastern Area State and Private Forestry, NA-FR-01-06.

40. Donnegan, J., Campbell, S., \& Azuma, D. (Tech. eds.) (2008). Oregon's forest resources, 20012005: Five-year forest inventory and analysis report. Portland, OR: U.S. Forest Service, Pacific Northwest Research Station, Gen. Tech. Rep. PNW-765.

41. Fajvan, M. A., \& Wood, P. B. (2010). Maintenance of eastern hemlock forests: Factors associated with hemlock vulnerability to hemlock woolly adelgid. In J. S. Rentch \& T. M. Schuler (Eds.), Proceedings from the conference on the ecology and management of high-elevation forests in the central and southern Appalachian Mountains; 2009 May 1415; Slatyfork, $W V$ (pp. 31-38). Newtown Square, PA: U.S. Department of Agriculture, Forest Service, Northern Research Station, Gen. Tech. Rep. NRS-P-64.

42. Forest Health Monitoring (1992). Forest health monitoring 1991 statistical summary. EPA/620/ R-94/028. Washington, DC: US Environmental Protection Agency.

43. Harper, R. A., McClure, N. D., Johnson, T. G., Green, J. F., Johnson, J. K., Dickinson, D. B., et al. (2009). Georgia's forests, 2004. Asheville, NC: U.S. Department of Agriculture Forest Service, Southern Research Station, Resour. Bull. SRS-149.

44. Haugen, D. E., Kangas, M., Crocker, S. J., Perry, C. H., Woodall, C. W., Butler, B. J., et al. (2009). 
North Dakota's forests 2005. Newtown Square, PA: U.S. Department of Agriculture, Forest Service, Northern Research Station, Resour. Bull. NRS-31.

45. Hess, N. J., Otrosina, W. J., Carter, E. A., Steinman, J. R., Jones, J. P., Eckhardt, L. G., et al. (2002). Assessment of loblolly pine decline in central Alabama. In K. W Outcalt (Ed.), Proceedings of the eleventh biennial southern silvicultural research conference (pp. 558-564). Asheville, NC: U.S. Department of Agriculture, Forest Service, Southern Research Station, Gen. Tech. Rep. SRS-48.

46. Juknys, R., \& Augustaitis, A. (1998). Indicators of crown and their application in forest health monitoring. Baltic Forestry, 2, 51-58.

47. Juknys, R., Augustaitis, A., Ozolinčius, R., \& Mozgeris, G. (2003). Crown indicators and their relationship with acid deposition: forest health monitoring case study in Baltic States. Baltic Forestry, 9, 42-50.

48. Klos, R. J., Wang, G. G., \& Bauerle, W. L. (2007). Assessment of the 1998-2001 drought impact on forest health in Southeastern forests: An analysis of drought severity using FHM data. In J. A. Stanturf (Ed.), Proceedings of the 14th biennial southern silvicultural research conference (pp. 553-554). Asheville, NC: U.S. Department of Agriculture, Forest Service, Southern Research Station, Gen. Tech. Rep. SRS-121.

49. Koch, L., Rogers, P., Frank, M., Atkins, D., \& Spiegel, L. (2001). Wyoming forest health report 1995-1998, a baseline report. Wyoming State Forestry Division and U.S. Department of Agriculture, Forest Service.

50. Kolb, T. E., \& McCormick, L. H. (1993). Impacts of pear thrips on a Pennsylvania sugarbush: Third year results. In A. R. Gillespie, G. R. Parker, P. E. Pope, \& G. Rink (Eds.), Proceedings of the 9th central hardwood forest conference (pp. 119129). St. Paul, MN: U.S. Department of Agriculture, Forest Service, North Central Forest Experiment Station, Gen. Tech. Rep. NC-161.

51. Leininger, T. D. (2002). Responses of tree crown conditions to natural and induced variations in throughfall. In K. W. Outcalt (Ed.), Proceedings of the eleventh biennial southern silvicultural research conference (pp. 92-96). Asheville, NC: U.S. Department of Agriculture, Forest
Service, Southern Research Station, Gen. Tech. Rep. SRS-48.

52. Lewis, T. E., \& Conkling, B. L. (Eds.) (1994). Forest health monitoring southeast loblolly/ shortleaf pine demonstration interim report. EPA/620/R-94/006. Washington, DC: US Environmental Protection Agency.

53. McCaskill, G. L., McWilliams, W. H., Barnett, C. J., Butler, B. J., Hatfield, M. A., Kurtz, C. M., et al. (2011). Maine's forests 2008. Newtown Square, PA: U.S. Department of Agriculture, Forest Service, Northern Research Station, Resour. Bull. NRS-48.

54. McWilliams, W. H., Arner, S. L., \& Barnett, C. J. (1997). Summary of mortality statistics and forest health monitoring results for the Northeastern United States. In S. G. Pallardy, R. A. Cecich, H. G. Garrett, \& P. S. Johnson, P. S. (Eds.), Proceedings of the 11th central hardwood forest conference (pp. 59-75). St. Paul, MN: U.S. Department of Agriculture, Forest Service, North Central Forest Experiment Station, Gen. Tech. Rep. NC-188.

55. McWilliams, W. H., Cassell, S. P., Alerich, C. L., Butler, B. J., Hoppus, M. L., Horsley, S. B., et al. (2007). Pennsylvania's Forest, 2004. Newtown Square, PA: U.S. Department of Agriculture, Forest Service, Northern Research Station, Resour. Bull. NRS-20.

56. Metzger, J. M., \& Oren, R. (2001). The effect of crown dimensions on transparency and the assessment of tree health. Ecological Applications, 11, 1634-1640.

57. Miles, P. D., Heinzen, D., Mielke, M. E., Woodall, C. W., Butler, B. J., Piva, R. J., et al. (2011). Minnesota's Forests 2008. Newtown Square, PA: U.S. Department of Agriculture, Forest Service, Northern Research Station, Resour. Bull. NRS-50.

58. Millers, I., Anderson, R., Burkman, W., \& Hoffard, W. (1992). Crown condition rating guide. Newtown Square, PA: U.S. Department of Agriculture, Forest Service, Northeastern Area State and Private Forestry.

59. Monleon, V. J., Azuma, D., \& Gedney, D. (2004). Equations for predicting uncompacted crown ratio based on compacted crown ratio and tree attributes. Western Journal of Applied Forestry, 19, 260-267. 
60. Morin, R. S., Barnett, C. J., Brand, G. J., Butler, B. J., Domke, G. M., Francher, S., et al. (2011). New Hampshire's Forests 2007. Newtown Square, PA: U.S. Department of Agriculture, Forest Service, Northern Research Station, Resour. Bull. NRS-53.

61. Morin, R. S., Barnett, C. J., Brand, G. J., Butler, B. J., De Geus, R., Hansen, M. H., et al. (2011). Vermont's Forests 2007. Newtown Square, PA: U.S. Department of Agriculture, Forest Service, Northern Research Station, Resour. Bull. NRS-51.

62. Morin, R. S., Jr., Liebhold, A. M., \& Gottschalk, K. W. (2004). Area-wide analysis of hardwood defoliator effects on tree conditions in the Allegheny Plateau. Northern Journal of Applied Forestry, 21, 31-39.

63. Morin, R. S., Liebhold, A. M., Gottschalk, K. W., Woodall, C. W., Twardus, D. B., White, R. L., et al. (2006). Analysis of forest health monitoring surveys on the Allegheny National Forest (19982001). Newtown Square, PA: U.S. Department of Agriculture, Forest Service, Northeastern Research Station, Gen. Tech. Rep. NE-339.

64. Morin, R. S., Liebhold, A. M, Gottschalk, K. W., Twardus, D. B., Acciavatti, R. E., White, R. L., et al. (2001). Forest health conditions on the Allegheny National Forest (1989-1999): Analysis of forest health monitoring surveys. Newtown Square, PA: U.S. Department of Agriculture, Forest Service, Northeastern Area, State and Private Forestry, NA-TP-04-01.

65. Nelson, M. D., Brewer, M., Woodall, C. W., Perry, C. H., Domke, G. M., Piva, R. J., et al. (2011). Iowa's Forests 2008. Newtown Square, PA: U.S. Department of Agriculture, Forest Service, Northern Research Station, Resour. Bull. NRS-52.

66. Northeastern Research Station (2002). Forest health monitoring in Connecticut 1996-1999. Newtown Square, PA: U.S. Department of Agriculture, Forest Service, Northeastern Research Station, INF-NE-153-02.

67. Northeastern Research Station (2003). Forest Health Monitoring in Delaware, 1996-1999. Newtown Square, PA: U.S. Department of Agriculture, Forest Service, Northeastern Research Station, NE-INF-162.

68. Northeastern Research Station (2002). Forest health monitoring in Maine 1996-1999. Newtown Square, PA: U.S. Department of
Agriculture, Forest Service, Northeastern Research Station, INF-NE-145-02.

69. Northeastern Research Station (2003). Forest health monitoring in Maryland 1996-1999. Newtown Square, PA: U.S. Department of Agriculture, Forest Service, Northeastern Research Station, INF-NE-160-03.

70. Northeastern Research Station (2002). Forest Health Monitoring in Massachusetts, 19961999. Newtown Square, PA: U.S. Department of Agriculture, Forest Service, Northeastern Research Station, INF-NE-149-02.

71. Northeastern Research Station, (2002). Forest Health Monitoring in New Hampshire, 19961999. Newtown Square, PA: U.S. Department of Agriculture, Forest Service, Northeastern Research Station, INF-NE-146-02.

72. Northeastern Research Station (2003). Forest health monitoring in New Jersey 1996-1999. Newtown Square, PA: U.S. Department of Agriculture, Forest Service, Northeastern Research Station, INF-NE-161-03.

73. Northeastern Research Station (2002). Forest Health Monitoring in New York, 1996-1999. Newtown Square, PA: U.S. Department of Agriculture, Forest Service, Northeastern Research Station, INF-NE-151-02.

74. Northeastern Research Station (2002). Forest Health Monitoring in Pennsylvania, 19981999. Newtown Square, PA: U.S. Department of Agriculture, Forest Service, Northeastern Research Station, INF-NE-158-02.

75. Northeastern Research Station (2002). Forest Health Monitoring in Rhode Island, 19961999. Newtown Square, PA: U.S. Department of Agriculture, Forest Service, Northeastern Research Station, INF-NE-156-02.

76. Northeastern Research Station (2002). Forest Health Monitoring in Vermont, 1996-1999. Newtown Square, PA: U.S. Department of Agriculture, Forest Service, Northeastern Research Station, INF-NE-147-02.

77. Northeastern Research Station (2002). Forest Health Monitoring in West Virginia, 19961999. Newtown Square, PA: U.S. Department of Agriculture, Forest Service, Northeastern Research Station, INF-NE-159-02.

78. Oswalt, C. M., Oswalt, S. N., Johnson, T. G., Chamberlain, J. L., Randolph, K. C., \& 
Coulston, J. W. (2009). Tennessee's forests, 2004. Asheville, NC: U.S. Department of Agriculture, Forest Service, Southern Research Station, Res. Bull. SRS-144.

79. Petrillo, H. A., Witter, J. A., \& Thompson, E. M. (2005). Michigan beech bark disease monitoring and impact analysis system. In C. A. Evans, J. A. Lucas, \& M. J. Twery (Eds.), Beech bark disease: proceedings of the beech bark disease symposium (pp. 48-51). Newtown Square, PA: U.S. Department of Agriculture, Forest Service, Northeastern Research Station, Gen. Tech. Rep. NE-331.

80. Piva, R. J., Moser, W. K., Haugan, D. D., Josten, G. J., Brand, G. J., Butler, B. J., et al. (2009). South Dakota's forests 2005. Newtown Square, PA: U.S. Department of Agriculture, Forest Service, Northern Research Station, Resour. Bull. NRS-35.

81. Pugh, S. A., Hansen, M. H., Pedersen, L. D., Heym, D. C., Butler, B. J., Crocker, S. J., et al. (2009). Michigan's forests 2004. Newtown Square, PA: U.S. Department of Agriculture, Forest Service, Northern Research Station, Resour. Bull. NRS-34.

82. Randolph, K. C. (2007). A comparison of tree crown condition in areas with and without gypsy moth activity. In R. E. McRoberts, G. A. Reams, P. C. Van Deusen, \& W. H. McWilliams (Eds.), Proceedings of the seventh annual forest inventory and analysis symposium; October 3-6, 2005; Portland, ME (pp. 107-113). Washington, DC: U.S. Department of Agriculture, Forest Service, Gen. Tech. Rep. WO-77.

83. Randolph, K. C. (2009). Crown Condition. In M. J. Ambrose \& B. L. Conkling (Eds.), Forest health monitoring: 2006 national technical report (pp. 65-110). Asheville, NC: U.S. Department of Agriculture, Forest Service, Southern Research Station, Gen. Tech. Rep. SRS-117.

84. Randolph, K. C. (2006). Descriptive statistics of tree crown condition in the Southern United States and impacts on data analysis and interpretation. Asheville, NC: U.S. Department of Agriculture, Forest Service, Southern Research Station, Gen. Tech. Rep. SRS-94.

85. Randolph, K. C. (2010). Equations relating compacted and uncompacted live crown ratio for common tree species in the South. Southern Journal of Applied Forestry, 34, 118-123.

86. Randolph, K. C. (2010). Technical note: Comparison of the arithmetic and geometric means in estimating crown diameter and crown cross-sectional area. Southern Journal of Applied Forestry, 34, 186-189.

87. Randolph, K., Bechtold, W., Morin, R., \& Zarnoch, S. (2009). From detection monitoring to evaluation monitoring - a case study involving crown dieback in northern white-cedar. In W. McWilliams, G. Moisen, \& R. Czaplewski (Comps.), Forest Inventory and Analysis (FIA) symposium 2008; October 21-23, 2008; Park City, UT. Proc. RMRS-P-56CD. Fort Collins, CO: U.S. Department of Agriculture, Forest Service, Rocky Mountain Research Station.

88. Randolph, K., Campbell, S., \& Christensen, G. (2010). Descriptive statistics of tree crown condition in California, Oregon, and Washington. Asheville, NC: U.S. Department of Agriculture, Forest Service, Southern Research Station, Gen. Tech. Rep. SRS-126.

89. Randolph, K., Morin, R. S., \& Steinman, J. (2010). Descriptive statistics of tree crown condition in the North Central United States. Asheville, NC: U.S. Department of Agriculture, Forest Service, Southern Research Station, Gen. Tec. Rep. SRS-125.

90. Randolph, K., Morin, R.S., \& Steinman, J. (2010). Descriptive statistics of tree crown condition in the Northeastern United States. Asheville, NC: U.S. Department of Agriculture, Forest Service, Southern Research Station, Gen. Tech. Rep. SRS-124.

91. Randolph, K. C., \& Moser, J. W., Jr. (2000). An evaluation of changes in tree crown characteristics to assess forest health in two Indiana state parks. Northern Journal of Applied Forestry, 21, $50-55$.

92. Randolph, K. C., \& Moser, W. K. (2009). Tree crown condition in Missouri, 2000-2003. Asheville, NC: U.S. Department of Agriculture Forest Service, Southern Research Station, Gen. Tech. Rep. SRS-113.

93. Randolph, K., \& Rose, A. (2009). Tree crown condition in Virginia before and after Hurricane Isabel (September 2003). In W. McWilliams, G. Moisen, \& R. Czaplewski, R. (Comps.), Forest 
Inventory and Analysis (FIA) symposium 2008; October 21-23, 2008; Park City, UT. Proc. RMRS-P-56CD. Fort Collins, CO: U.S. Department of Agriculture, Forest Service, Rocky Mountain Research Station.

94. Randolph, K. C., \& Seaver, B. (2007). An alternative to traditional goodness-of-fit tests for discretely measured continuous data. Forest Science, 53, 590-599.

95. Randolph, K., \& Thompson, M. T. (2010). Descriptive statistics of tree crown condition in the United States Interior West. Asheville, NC: U.S. Department of Agriculture, Forest Service, Southern Research Station, Gen. Tech. Rep. SRS-127.

96. Rentch, J., Fajvan, M. A., Evans, R. A., \& Onken, B. (2009). Using dendrochronology to model hemlock woolly adelgid effects on eastern hemlock growth and vulnerability. Biological Invasions, 11, 551-563.

97. Riitters, K., \& Tkacz, B. (2004). The US Forest Health Monitoring Program. In B. Wiersma (Ed.), Environmental Monitoring (pp. 669683). Boca Raton, FL: CRC Press.

98. Rogers, P., Atkins, D., Frank, M., \& Parker, D. (2001). Forest health monitoring in the Interior West, a baseline summary of forest issues, 19961999. U.S. Department of Agriculture, Forest Service, Gen. Tech. Rep. RMRS-75.

99. Rogers, P. C., O'Connell, B., Mwang'ombe, J., Madoffe, S., \& Hertel, G. (2008). Forest health monitoring in the Ngangao Forest, Taita Hills, Kenya: a five year assessment of change. Journal of East African Natural History, 97, 3-17.

100. Rogers, P., Schomaker, M., McLain, W., \& Johnson, S. (1998). Colorado forest health report 1992-95: a baseline assessment. Ogden, UT: U.S. Department of Agriculture, Forest Service, Rocky Mountain Research Station and Fort Collins, CO: Colorado State Forest Service.

101. Rose, A. K. (2007). Virginia's forests, 2001. Asheville, NC: U.S. Department of Agriculture Forest Service, Southern Research Station, Resour. Bull. SRS-120.

102. Rose, A. K. (2009). Virginia's forests, 2007. Asheville, NC: U.S. Department of Agriculture Forest Service, Southern Research Station, Resour. Bull. SRS-159.
103. Rosson, J. F., \& Rose, A. K. (2010). Arkansas' forests, 2005. Asheville, NC: U.S. Department of Agriculture Forest Service, Southern Research Station, Resour. Bull. SRS-166.

104. Rudis, V. A., Carraway, B., Sheffield, R. M., Oswalt, S. N., \& Chamberlain, J. L. (2008). East Texas forests, 2003. Asheville, NC: U.S. Department of Agriculture Forest Service, Southern Research Station, Resour. Bull. SRS137.

105. Schaberg, P. G., Tilley, J. W., Hawley, G. J., DeHayes, D. H., \& Bailey, S. W. (2006). Associations of calcium and aluminum with the growth and health of sugar maple trees in Vermont. Forest Ecology and Management, 223, 159-169.

106. Schomaker, M. E., Zarnoch, S. J., Bechtold, W. A., Latelle, D. J., Burkman, W. G., \& Cox, S. M. (2007). Crown-condition classification: a guide to data collection and analysis. Asheville, NC: U.S. Department of Agriculture Forest Service, Southern Research Station, Gen. Tech. Rep. SRS-102.

107. Sims, N. C., Stone, C., Coops, N. C., \& Ryan, P. (2007). Assessing the health of Pinus radiata plantations using remote sensing data and decision tree analysis. New Zealand Journal of Forestry Science, 37, 57-80.

108. Smith, W. D., \& Conkling, B. L. (2005). Analyzing forest health data. Asheville, NC: U.S. Department of Agriculture, Forest Service, Southern Research Station, Gen. Tech. Rep. SRS-77.

109. Starkey, D. A., \& Guldin, J. M. (2004). Crown health of reserve hardwood trees following reproduction cutting in the Ouachita Mountains. In J. M. Guldin (Tech. comp.), Ouachita and Ozark Mountains symposium: ecosystem management research (pp. 92-97). Asheville, NC: U.S. Department of Agriculture, Forest Service, Southern Research Station, Gen. Tech. Rep. SRS-74.

110. Steinman, J. (2004). Forest health monitoring in the northeastern United States: disturbances and conditions during 1993-2002. Newtown Square, PA: U.S. Department of Agriculture, Forest Service, Northeastern Area State and Private Forestry, NA-TP-01-04. 
111. Steinman, J. (2000). Tracking the health of trees over time on forest health monitoring plots. In M. Hansen \& T. Burk (Eds.), Integrated tools for natural resources inventories in the 21st century; 1998 August 16-19; Boise, ID (pp. 334-339). St. Paul, MN: U.S. Department of Agriculture, Forest Service, North Central Forest Experiment Station, Gen. Tech. Rep. NC-212.

112. Stolte, K. W., Conkling, B., Campbell, S., \& Gillespie, A. (2002). Forest health indicators. Forest Inventory and Analysis Program. FS746. Washington, DC: U.S. Department of Agriculture, Forest Service.

113. Stoyenoff, J., Witter, J., \& Leutscher, B. (1998). Forest health in the North Central states. Ann Arbor, MI: University of Michigan, School of Natural Resources and Environment.

114. Toney, C., \& Reeves, M. C. (2009). Equations to convert compacted crown ratio to uncompacted crown ratio for trees in the interior west. Western Journal of Applied Forestry, 24, 76-82.

115. Turner, J. A., Oswalt, C. M., Chamberlain, J. L., Conner, R. C., Johnson, T. G., Oswalt, S. N., \& Randolph, K. C. (2008). Kentucky's Forests, 2004. Asheville, NC: U.S. Department of Agriculture, Forest Service, Southern Research Station, Resour. Bull. SRS-129.

116. Westfall, J. A., Bechtold, W. A., \& Randolph, K. C. (2009). Section 1: Tree Crown Indicator. In J. A. Westfall (Ed.), FIA national assessment of data quality for forest health indicators (pp. 3-15). Newtown Square, PA: U.S. Department of Agriculture, Forest Service, Northeastern Research Station, Gen. Tech. Rep. NRS-53.

117. Widmann, R. H., Balser, D., Barnett, C., Butler, B. J., Griffith, D. M., Lister, T. W., et al. (2009). Ohio forests: 2006. Newtown Square, PA: U.S. Department of Agriculture, Forest Service, Northern Research Station, Resour. Bull. NRS-36.

118. Widmann, R. H., Dye, C. R., \& Cook, G. W. (2007). Forests of the Mountain State. Newtown Square, PA: U.S. Department of Agriculture, Forest Service, Northern Research Station, Resour. Bull. NRS-17.

119. Wiersma, G. B., Elvir, J. A., \& Eckhoff, J. (2004). Efficacy of forest health monitoring indicators to evince impacts on a chemically manipulated watershed. In G. B. Wiersma (Ed.), Environmental Monitoring (pp. 283305). Boca Raton, FL: CRC Press.

120. Wiersma, G. B., Elvir, J. A., \& Eckhoff, J. D. (2007). Forest vegetation monitoring and foliar chemistry of red spruce and red maple at Acadia National Park in Maine. Environmental Monitoring and Assessment, 126, 27-37.

121. Will-Wolf, S., \& Jovan, S. (2009). Lichens, ozone, and forest health - exploring cross-indicator analyses with FIA data. In W. McWilliams, G., Moisen, \& R. Czaplewski (Comps.), Forest Inventory and Analysis (FIA) Symposium 2008; October 21-23, 2008; Park City, UT. Proc. RMRS-P-56CD. Fort Collins, CO: U.S. Department of Agriculture, Forest Service, Rocky Mountain Research Station.

122. Woodall, C., Johnson, D., Gallion, J., Perry, C., Butler, B., Piva, R., et al. (2005). Indiana's forests 1999-2003 (Part A). St. Paul, MN: U.S. Department of Agriculture, Forest Service, North Central Research Station, Resour. Bull. NC-253A.

123. Woodall, C. W., Amacher, M. C., Bechtold, W. A., Coulston, J. W., Jovan, S., Perry, C. H., et al. (2010). Status and future of the forest health indicators program of the USA. Environmental Monitoring and Assessment, 177, 419-436.

124. Woodall, C. W., Webb, M. N., Wilson, B. T., Settle, J., Piva, R. J., Perry, C. H., et al. (2011). Indiana's Forests 2008. Newtown Square, PA: U.S. Department of Agriculture, Forest Service, Northern Research Station, Resourc. Bull. NRS-45.

125. Yaussy, D. A., Hutchinson, T. F., \& Sutherland, E. K. (2003). Structure, composition, and condition of overstory trees. In E. K. Sutherland \& T. F. Hutchinson (Eds.), Characteristics of mixed oak forest ecosystems in southern Ohio prior to the reintroduction of fire (pp. 99-111). Newtown Square, PA: U.S. Department of Agriculture, Forest Service, Northeastern Research Station, Gen. Tech. Rep. NE-299.

126. Zarnoch, S. J., Bechtold, W. A., \& Stolte, K. W. (2004). Using crown condition variables as indicators of forest health. Canadian Journal of Forest Research, 34, 1057-1070. 


\section{References}

Alexander, S. A., \& Barnard, J. E. (1992). Forest health monitoring 1992 activities plan. EPA/620/R-93/002. Washington, DC: US Environmental Protection Agency.

Alexander, S. A., \& Palmer, C. J. (1999). Forest health monitoring in the United States: first four years. Environmental Monitoring and Assessment, 55, 267-277.

Alexander, S. A., Carlson, J. A., \& Barnard, J. E. (1992). The visual damage survey: a study to evaluate the eastern forest condition. In D. H. McKenzie, D. E. Hyatt, \& V. J. McDonald (Eds.), Ecological indicators volume 1 (pp. 361-372). New York: Elsevier Applied Science.

Allen, D. C., Molloy, A. W., Cooke, R. R., \& Pendrel, B. A. (1995). A ten-year regional assessment of sugar maple mortality. In S. B. Horsley \& R. P. Long (Eds.), Sugar maple ecology and health: Proceedings of an international symposium (pp. 27-45). Radnor: U.S. Department of Agriculture, Forest Service, Northeastern Research Station. Gen. Tech. Rep. NE-261.

Anderson, R. L., \& Belanger, R. P. (1987). A crown rating method for assessing tree vigor of loblolly and shortleaf pines. In D. R. Phillips (Comp.), Proceedings of the 4th biennial southern silvicultural research conference (pp. 538-543). Asheville: U.S. Department of Agriculture, Forest Service, Southeastern Forest Experiment Station, Gen. Tech. Rep. SE-42.

Applegate, J. R., \& Steinman, J. (2005). A comparison of tree health among forest types and conditions at Fort A.P. Hill, Virginia. Southern Journal of Applied Forestry, 29, 143-147.

Bechtold, W., Tkacz, B., \& Riitters, K. (2007). The historical background, framework, and application of forest health monitoring in the United States. In Proceedings of the international symposium on forest health monitoring; 2007 January 30-31; Seoul, Republic of Korea (pp. 1940). Korea Forest Conservation Movement.

Brooks, R. T., Dickson, D. R., Burkman, W. B., Millers, I., Miller-Weeks, M., Cooter, E., et al. (1992). Forest health monitoring in New England: 1990 annual report. Radnor: U.S. Department of Agriculture, Forest Service, Northeastern Forest Experiment Station. Resour. Bull. NE-125.

Chojnacky, D. C. (Comp.) (1991). Eastern forest health monitoring field measurements guide, 5th draft. Research Triangle Park: U.S. Department of Agriculture, Forest Service.

Conkling, B. L., \& Byers, G. E. (Eds.). (1992). Forest health monitoring field methods guide. Internal report. Las Vegas: US Environmental Protection Agency.

D’Eon, S. P., Magasi, L. P., Lachance, D., \& DesRochers, P. (1994). ARNEWS: Canada's national forest health monitoring plot network manual on plot establishment and monitoring (revised). Information Report PI-X-117. Chalk River: Petawawa National Forestry Institute.

Ehrlich, J. (1939). A preliminary study of root diseases in western white pine. Missoula: U.S. Department of Agriculture, Forest Service, Northern Rocky Mountain Forest and Range Experiment Station, Station Paper No. 1.

Eichhorn, J., Roskams, P., Ferretti, M., Mues, V., Szepesi, A., \& Durrant, D. (2010). Visual assessment of crown condition and damaging agents. Manual Part IV. In Manual on methods and criteria for harmonized sampling, assessment, monitoring and analysis of the effects of air pollution on forests. Hamburg, Germany: UNECE ICP Forests Programme Coordinating Centre. http://www.icp-forests.org/Manual.htm. Accessed 9 February 2010.

Hall, J. P. (1995). ARNEWS assesses the health of Canada's forests. The Forestry Chronicle, 71, 607-613.

ICP-Forests (2010). Europe's Forests 1985-2010: 25 Years of monitoring forest condition by ICP Forests. Hamburg, Germany: International Co-operative Programme on Assessment and Monitoring of Air Pollution Effects on Forests (ICP Forests). http://www.icp-forests.org/pdf/25 years_en.pdf. Accessed August 2010.

Innes, J. L. (1993). Forest health: Its assessment and status. UK: CAB International.

Lewis, T. E., \& Conkling, B. L. (Eds.) (1994). Forest health monitoring: Southeast loblolly/shortleaf pine demonstration interim report. EPA/620/SR-94/006. Washington, DC: US Environmental Protection Agency.

McFadden, M. W. (1991). The North American sugar maple decline project: Planning, organization, and implementation. In D. P. Burns (Tech. coord.), Research management for the future; 1990 August 5-11; Montreal, PQ (pp. 3-9). Radnor: U.S. Department of Agriculture, Forest Service, Northeastern Forest Experiment Station, Gen. Tech. Rep. NE-157.

Messer, J. J., Linthurst, R. A., \& Overton, W. S. (1991). An EPA program for monitoring ecological status and trends. Environmental Monitoring and Assessment, 17, 67-78.

Millers, I., Shriner, D., \& Rizzo, D. (1989). History of hardwood decline in the eastern United States. Radnor: U.S. Department of Agriculture, Forest Service, Northeastern Forest Experiment Station. Gen. Tech. Rep. NE-126.

Millers, I., Lachance, D., Burkman, W. G., \& Allen, D. C. (1991). North American sugar maple decline project: organization and field methods. Radnor: U.S. Department of Agriculture, Forest Service, Northeastern Forest Experiment Station. Gen. Tech. Rep. NE-154.

Petrillo, H. A., Witter, J. A., \& Thompson, E. M. (2005). Michigan beech bark disease monitoring and impact analysis system. In C. A. Evans, J. A. Lucas, \& M. J. Twery (Eds.), Beech bark disease: Proceedings of the beech bark disease symposium (pp. 48-51). Newtown Square: U.S. Department of Agriculture, Forest Service, Northeastern Research Station. Gen. Tech. Rep. NE-331.

Redfern, D. B., \& Boswell, R. C. (2004). Assessment of crown condition in forest trees: comparison of methods, sources of variation and observer bias. Forest Ecology and Management, 188, 149-160.

Rentch, J., Fajvan, M. A., Evans, R. A., \& Onken, B. (2009). Using dendrochronology to model hemlock woolly adelgid effects on eastern hemlock growth and vulnerability. Biological Invasions, 11, 551-563.

Riitters, K., \& Tkacz, B. (2004). The US forest health monitoring program. In B. Wiersma (Ed.), Environmental monitoring (pp. 669-683). Boca Raton: CRC.

Riitters, K. H., Law, B. E., Kucera, R. C., Gallant, A. L., DeVelice, R. L., \& Palmer, C. J. (1992). A selection of forest condition indicators for monitoring. Environmental Monitoring and Assessment, 20, 21-33.

Schomaker, M. E., Zarnoch, S. J., Bechtold, W. A., Latelle, D. J., Burkman, W. G., \& Cox, S. M. (2007). Crown-condition 
classification: A guide to data collection and analysis. Asheville: U.S. Department of Agriculture, Forest Service, Southern Research Station. Gen. Tech. Rep. SRS-102.

Snell, W. H. (1931). Forest damage and the white pine blister rust. Journal of Forestry, 29, 68-78.

Starkey, D. A., \& Guldin, J. M. (2004). Crown health of reserve hardwood trees following reproduction cutting in the Ouachita Mountains. In J. M. Guldin (Tech. comp.), Ouachita and Ozark Mountains symposium: ecosystem management research (pp. 92-97). Asheville: U.S. Department of
Agriculture, Forest Service, Southern Research Station, Gen. Tech. Rep. SRS-74.

U.S. Department of Agriculture, Forest Service. (2007). Forest inventory and analysis national core field guide. Volume 1: field data collection procedures for phase 2 plots, version 4.0. Washington, DC: U.S. Department of Agriculture, Forest Service.

Zedaker, S. M., \& Nicholas, N. S. (1990). Quality assurance methods manual for forest site classification and field measurements. EPA/600/3/90/082. Corvallis: US Environmental Protection Agency. 